\title{
Drift algae and small fish in coastal waters of northeastern New Zealand
}

\author{
Michael J. Kingsford* \\ University of Auckland, Zoology Department, Marine Laboratory, R. D. Leigh, New Zealand
}

\begin{abstract}
Small fish associated with drift algae, and in open water adjacent to algae, were sampled off the northeastern coast of New Zealand (1981 to 1984). Estimates of the abundance of drift algae and rates of colonisation of fish to drift algae were also obtained. A number of species of fish were more abundant around drift algae than in open water (e.g. representatives of Monacanthidae, Arripidae, Emmelichthyidae, Syngnathidae, Clinidae, Tripterygiidae). Although some fish associated with algae were preflexion forms, most were postflexion or juvenile forms. Relationships between weight of drift algae and numbers of fish varied among times. Some small fish were abundant in surface waters and showed no association with drift algae (e.g. representatives of Tripterygiidae, Clupeidae, Engraulididae, Pleuronectidae, Bothidae). Abundance of total drift algae at nearshore and offshore stations over a period of $2.5 \mathrm{yr}$ was highly variable. Seasonal peaks in abundance of Sargassum sinclairii were found from November to January and appeared to relate to the demography of this species. Most clumps of drift algae were $<100 \mathrm{~g}$. A detailed examination of the abundance of algae nearshore showed that the input of drift algae to reef environments is extremely variable among times and may relate to detachment of algae from reefs and conditions that facilitate onshore movements of drift from coastal waters. Fish were quickly attracted to algae left to drift in coastal waters for under $8 \mathrm{~h}$. Colonisation relationships and developmental forms of fish attracted to algae varied among species. Drifting algae is periodically abundant in coastal waters and has an important influence on the distribution, and potentially the movements, of some presettlement fish.
\end{abstract}

\section{INTRODUCTION}

A focus on structure in the pelagic environment can provide important information on the distribution, movements and survivorship of ichthyoplankton. Structure can exist in abiotic or biotic forms. The distribution of small fish may be influenced by hydrological processes (e.g. Legendre \& Demers 1984, Kingsford 1990), passively drifting objects such as flotsam (Gooding \& Magnuson 1967. Hunter \& Mitchell 1967), drift algae (Mitchell \& Hunter 1970, Dooley 1972, Lenanton et al. 1982, Safran \& Omori 1990) and slow-moving animals, e.g. gelatinous zooplankton (Mansueti 1963, Janssen \& Harbison 1981). Drift algae may be found in sufficient quantities to be of importance in affecting the distribution of small fish, both nearshore and offshore, especially in temperate regions (Kingsford in press).

Kingsford \& Choat (1985) demonstrated that the association of small fish with drift algae was the result of colonisation from open water rather than immigra-

\footnotetext{
- Present address: School of Biological Sciences A08, University of Sydney, NSW 2006, Australia
}

tion from coastal reefs. The study was limited, however, to one time of year (December-January). The purpose of my study was to build on this initial work by examining temporal and spatial abundance patterns of small fish in open water and associated with drift algae, as well as the distribution patterns of algae. Concurrent sampling of drift algae and open water at different times of the year enabled an assessment of the influence that drift algae has on different types on fish. Small fish around drift algae are often well-pigmented pelagic juveniles (Hunter \& Mitchell 1967). It was important, therefore, that the sizes of fish in open water were compared with those around algae.

Although associations between fish, flotsam, drift algae and gelatinous zooplankton have been documented, there is a paucity of information on the abundance of these structures in the pelagic environment. The abundance of drift algae may vary seasonally, as has been found in estuaries (Benz et al. 1979) and surf beaches (Lenanton et al. 1982). In open coastal systems some algal species are deciduous (e.g. Sargassum spp.), shedding most of the thallus from rocky reefs seasonally (Prince \& O'Neal 1979, Schiel 1985). Hence 
the importance of drift algae in influencing the distribution of fish at different times of year may vary in relation to the demography of the plants themselves and the occurrence of storms that detach plants.

Spatial patterns in the distribution of drift algae are also important. The distance that algae are found from shore may determine the types of fish that colonise it, and the changing distribution patterns of the algae may reflect those of the fish. Furthermore, for small fish of species found as adults nearshore, drift algae might have an influence on recruitment patterns where algae move onshore (Kingsford \& Milicich 1987).

Fish are quickly attracted to floating objects (Hunter \& Mitchell 1968, Kingsford \& Choat 1985). Information on colonisation rates and sizes of fish would be useful for interpreting the effect drift algae has on the distribution of fish, as it drifts through an area.

The specific questions posed in this study were: How do the abundances and species composition of fish associated with drift algae vary seasonally? Does the abundance of drift algae vary seasonally at different distances from shore, and over short time periods among localities nearshore? How quickly are tish attracted to drift algae from open water?

\section{MATERIAL AND METHODS}

Seasonal patterns of small fish associated with drift algae. Samples around drift algae and in open water were compared over a period of $18 \mathrm{mo}$, and at different distances from shore. This allowed an assessment of the influence that drift algae had on the distribution patterns of small fish in surface waters. Seasonal trends and abundances of fish at different distances from shore were also described.

The influence that drift algae had on the distributions of small fish was assessed using the methods of Kingsford \& Choat (1985). Seines around drift algae were compared with 3 types of sampling procedures in open water. These were: (1) open water seines; (2) seines plus $1 \mathrm{~kg}$ of soaked algae - all animals were removed by soaking algae in freshwater for 12 to $24 \mathrm{~h}$; (3) $5 \mathrm{~min}$ ichthyoplankton hauls with a $0.28 \mathrm{~mm}$ mesh net. Approximately 100 to $300 \mathrm{~m}^{3}$ of seawater was sampled with conventional surface ichthyoplankton tows. Towing speeds varied between 70 and $80 \mathrm{~cm} \mathrm{~s}^{-1}$, and the volume of water filtered was measured with a General Oceanics 2030 flowmeter. The cylinder cone net had 1:6 mouth area to open area of mesh. A $10 \times 2 \mathrm{~m}$ plankton-mesh purse seine net $10.28 \mathrm{~mm}$ meshj was used to sample drift algae and open water (Kingsford \& Choat 1985); volume of water sampled by the net was ca $16 \mathrm{~m}^{3}$. Seines plus $1 \mathrm{~kg}$ of soaked algae were used to address the question of whether organisms captured in

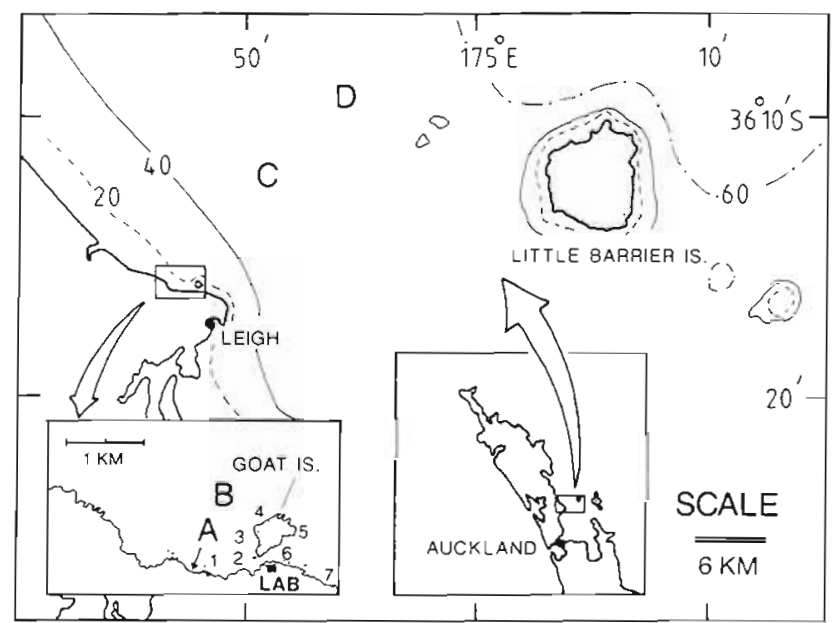

Fig. 1. Northeastern New Zealand, showing Stations A to D where drift algae and fish were sampled; depth contours are given in meters. Drift algae were also sampled at Localities 1 to $f$ within Stn $A$ (see Table 3 )

seines around algae were so alarmed by our activity that they simply retreated to the nearest clump of drift algae. Soaked algae were released in open water and seined within $1 \mathrm{~min}$.

Seines were made around drift algae and compared with open water samples over an $18 \mathrm{mo}$ period (December 1981 to May 1983) at 4 stations on a transect extending to $18 \mathrm{~km}$ offshore (Stns A to D, Fig. 1). Sampling was carried out within a $2 \mathrm{~km}$ zone of these station points, parallel to the shore; distances from shore were: $\operatorname{Stn} \mathrm{A}_{1}<100 \mathrm{~m} ; \mathrm{Stn} \mathrm{B}_{1} 400$ to $800 \mathrm{~m}_{i} \operatorname{Stn} \mathrm{C}_{\text {, }}$ $10 \mathrm{~km}$; Stn D, $18 \mathrm{~km}$. At each station drift algae were sampled when encountered. Three clumps of algae were seined and the results compared with the 3 types of samples taken in adjacent open water, each replicated 3 times. Additional seine samples were taken to investigate whether there was a correlation between the weight of an algal clump and the number of fish around it. Size frequency information $(\mathrm{SL}=$ standard length or notochord length in very small fish) was obtained on fish around algae and in open water, as it was possible that only a limited size range of a species was associated with drift algae. Terminology is according to Leis \& Rennis (1983) and Kingsford \& Choat (1985).

Abundance of fish around drift algae were compared with the number of fish in open water samples, and counts were expressed as number per $100 \mathrm{~g}$ of algae. This was done for 4 reasons. (1) Work by Kingsford \& Choat (1985) showed there was a positive correlation between the size of an algal clump and the number of fish associated with it. Seasonal trends could be misinterpreted, therefore, if clumps of different sizes were seined at different times and fish abundances were not corrected for the size of algae. (2) The mean size of 
algal clumps weighed from 1981 to 1982 was 100 g. (3) Number of fish could be related to abundances of drift algae. (4) The expression of fish abundances as number per $100 \mathrm{~g}$ was more conservative than values uncorrected for weight of algae. To complement these data, relationships between the size of algal clumps and number of fish are given for different times of the year, as it was possible that this relationship would vary among times. This information was also used to describe the proportional representation of fish species around algae at different times of the year.

Abundance of algae. Seasonal patterns were examined at each of the 4 sampling stations. Clumps of drift algae were counted and their weight estimated on a number of occasions over a 2.5 yr period, from 1981 to 1984. The number of sampling times at each station were: Stn A, 30; Stn B, 24; Stn C, 27; Stn D, 16. Algae were counted within five $200 \times 40 \mathrm{~m}$ floating transects. Floating transects were laid out on random bearings, by dropping 11 current-indicating drogues spaced at $20 \mathrm{~m}$ intervals in a straight line. Exact spacing was achieved by towing a $20 \mathrm{~m}$ rope behind the boat and dropping each consecutive drogue as the rope passed the previous one. The boat then travelled down one side of the transect and back up the other. A pilot study indicated that precise estimates of drift algae abundance could be obtained in this way (Kingsford 1986). Clumps of algae were counted and weighed with a spring balance. The weights of some clumps of algae were estimated visually when considerable experience had been gained. From October 1983 onward a different sampling procedure was adopted, as described in Kingsford \& Choat (1986). All results for seasonal patterns are expressed as units per 0.8 hectares. Counts were made at any time during the day. The possibility that time of day influenced abundance estimates (via tidal change or change in the wind direction) was investigated at $\operatorname{Stn} \mathrm{A}$ in a pilot study. Although mean values varied among days, similar mean values were recorded within days (Kingsford 1986). Data are only presented on weight of algae in transects, because similar patterns of abundance were found for number of clumps per unit area (Kingsford 1986).

Abundances among localities were examined at 7 localities separated by 400 to $700 \mathrm{~m}$ within Stn A (Fig. 1) to see whether there was a differential accumulation of algae among localities. This was done on 8 occasions between 10 October 1983 and 11 April 1984. At each locality algae were sampled within three $2000 \mathrm{~m}^{2}$ transects.

Colonisation of experimental algae. Experiments were used to compare the rates at which fish were attracted to drift algae from open water, among times, fish species, and distance from shore. Experiments were also used to test for differences in the abundances of fish at different depths. In all experiments $1 \mathrm{~kg}$ clumps of Carpophyllum maschalocarpum, which had been cut from rocky reefs, were soaked in freshwater for 24 h. Kingsford \& Choat (1985) showed that this process removed any fish and mobile invertebrates associated with the algae. Free-floating algae were then placed in the sea and left to drift for different times before they were seined. Algae were released at times between 08:45 and 09:15 $\mathrm{h}$ and the clumps were spaced ca $50 \mathrm{~m}$ apart. Drift times were expressed as averages - those algae which drifted for longer than 45 min were recaptured within $30 \mathrm{~min}$ of the mean drift time. To describe the size at which fish colonise drift algae, the size-frequency distributions of fish on experimental algae were compared with the sizes of fish present around natural drift algae.

Expt 1 examined the colonisation of algae over time in January 1982 at $\operatorname{Stn}$ C. The drift times of algae (h:min) were: $0: 01,0: 45,3: 15,5: 00$, and $8: 15$, with 3 replicate clumps of algae for each time. All algae in surface waters were seined. Three free-floating clumps of algae were hung at $15 \mathrm{~m}$ for $6: 30$ to $7: 15$. The $15 \mathrm{~m}$ line was weighted and algae hung to the side on a lateral monofilament trace; a diver counted the fish and the results were compared with those from seines.

Expt 2 examined the colonisation of algae with time in December 1982 at Stn C. The drift times of algae (h:min) were: 0:01, 1:30, 4:50, 6:45. In Expt 1 the results for some species of fish gave standard errors of up to $100 \%$ of the mean. In addition, there was a reasonable possibility that a few clumps of soaked algae would be lost. For these reasons the replication was increased from 3 to 5 clumps of algae for each time.

\section{RESULTS}

\section{Seasonal patterns of small fish associated with drift algae and in open water}

Gilloblennius spp. were found in greatest numbers around drift algae (Fig. 2). With the exception of December 1981 at Stn B, this was true of all stations. Many of this group were captured in aggregations of varying sizes around clumps of drift algae, which explains the large standard errors shown in Fig. 2. The occurrence of this species was strongly seasonal - low densities were captured in June, abundances peaked in November and few were captured in January. From September to December Gilloblennius spp. were often the most abundant fish around algae. Although the highest densities were found at $\operatorname{Stn} C$, fish were abundant at all distances from shore. A broad size range of these fish was encountered around drift algae, from fish with fin-folds to those with adult fin-ray counts 

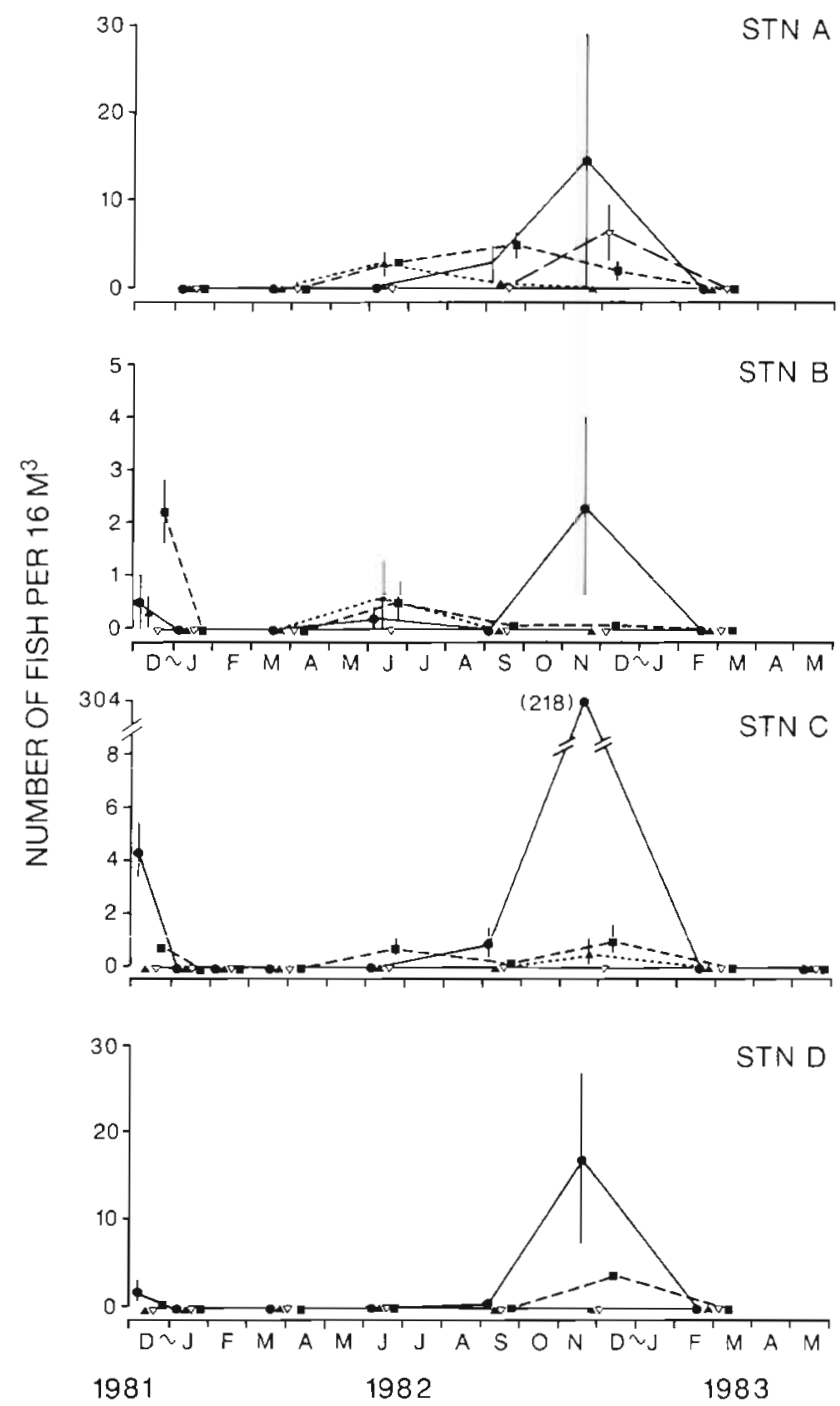

Fig. 2. Number of Gilloblennius spp. associated with drift algae (continuous line) and in open water at Stns $A$ to D, over a period of 18 mo. Means $\pm S E, n=3 ;(\bullet-$ seine $+100 \mathrm{~g}$ of drift algae; $(\Delta-\Lambda)$ open water seine; $(\nabla-\nabla)$ seine $+1 \mathrm{~kg}$ of soaked algae; (-) ichthyoplankton tow with $0.28 \mathrm{~mm}$ mesh net. Number in parentheses $(\operatorname{Stn} C)=S E$

(Table 1; November 1982). This indicated that Gilloblennius spp. may associate with algae at any time during its presettlement phase.

Cryptically coloured Parika scaber, with full adult fin-ray counts, were characteristic components of the drift ichthyofauna from November to January and highest numbers were captured offshore (Tables $1 \& 2$; see Kingsford \& Milicich 1987). Only 11 fish were captured in open water over the study period.

A number of species were captured in high numbers around drift algae that were rarely or never captured in any of the 3 sampling procedures from open water. Arripis trutta and Plagiogeneion rubiginosis were captured in large aggregations around drift algae in autumn and winter and largest aggregations were found at Stns C \& D offshore (Tables 1 \& 2). Although Trachurus spp. were captured in open water (November to March) largest fish were caught around drift algae. When any of the above 3 species were captured, large differences in abundance were found among replicates. Other species captured around algae that were rare or absent in open water samples included syngnathids, carangids, kyphosids, mugilids, clinids, and others. With the exception of some small Aldrichetta forsteri and Girella tricuspidata all of these fishes had adult fin-ray counts. Of interest were the large sizes of the syngnathids, and their association with algae at all times of the year. Many of the individuals were adults and so were not considered to be in the presettlement phase of their life history.

Relationships between the weight of a clump of drift algae and total numbers of fish are presented in Fig. 3 (for 5 out of 9 times). The relationship varied among times, and 5 out of the 9 correlations were significant and positive. These differences can be explained by the types of fish that associated with algae at different times of the year. The percentages of each type of fish that contributed to the correlations in Fig. 3 are given in Table 2. Where correlations were not significant, fishes that aggregated into large groups around algae were abundant (e.g. Gilloblennius spp., Arripis trutta, Plagiogeneion rubiginosus, and Trachurus spp.). Where correlations were significant, secretive fish such as Parika scaber often predominated (Fig. 3a, d, Table 2). It should be noted that very small clumps of algae $(<50 \mathrm{~g}$ ) often had fish associated with them (e.g. Fig. 3).

Seasonality in the proportional representation of fish around algae can be seen in Table 2. From September to December Gilloblennius spp. was usually the most abundant taxon, while Parika scaber ranked first or second from November to January. Aldrichetta forsteri were also captured regularly over spring and summer. Cristiceps auranticus were caught in highest numbers in summer. From February to March Plagiogeneion rubiginosus and Trachurus spp. predominated. Arripis trutta and Upeneichthys lineatus were also caught at this time. In June A. trutta were most abundant. Although Forsterygion spp. were also captured around algae at this time, they were usually most abundant in open water.

Some species of fish were often captured in open water, but were rare around algae. The 4 most abundant groups that showed this pattern were Forsterygion spp., Sardinops neopilchardus, Engraulis australis and pleuronectids (Rhombosolea spp. and Peltorhamphus latus). For brevity, data are only presented for Stn A (Fig. 4); similar results were found for Stns B to D. Although Forsterygion spp. and Gilloblennius spp. are in the same family, their affinity for algae differed 
Table 1. Sizes (standard length, $\mathrm{mm}$ ) of rare fish associated with drift algae and in open water at Stns A to D over the entire study period. Single values = standard length. Groups of fish with 2 or less individuals caught included: Muraenidae, Sprattus antipodium, Trachichthyidae, Cheilodactylidae, Eleotridae, Serranidae. "Subsample of total fish caught; see graphs for patterns of abundance. ND: no data on size

\begin{tabular}{|c|c|c|c|c|c|c|c|}
\hline \multirow[t]{2}{*}{ Family } & \multirow[t]{2}{*}{ Species } & \multicolumn{3}{|c|}{ Drift algae } & \multicolumn{3}{|c|}{ Open water } \\
\hline & & Mean & Range & $\mathrm{n}$ & Mean & Range & $\mathrm{n}$ \\
\hline Clupeidae" & Sardinops neopilchardus & 4.3 & $2-16$ & 59 & 7.5 & $2-20$ & 284 \\
\hline Galaxidae & Galaxias maculatus & 37 & $34-40.5$ & 3 & 37 & $34-40.5$ & 11 \\
\hline Engraulididae ${ }^{\circ}$ & Engraulis australis & 4.6 & $3-18$ & 104 & 5.2 & $2-20$ & 229 \\
\hline Moridae & $\begin{array}{l}\text { Auchenoceros punctatus } \\
\text { Pseudophycis spp. }\end{array}$ & 22.7 & & & 3.4 & $2.1-5$ & 14 \\
\hline Hemiramphidae & Hyporhamphus ihi & 9.5 & $6.5-13.2$ & 3 & 8 & & \\
\hline Syngnathidae & $\begin{array}{l}\text { Lissocampus filum } \\
\text { Stigmatophora longirostris } \\
\text { Hippocampus abdominalis }\end{array}$ & $\begin{array}{l}18.7 \\
80 \\
83\end{array}$ & $\begin{array}{c}14.3-23.2 \\
40-139 \\
32-127\end{array}$ & $\begin{array}{r}3 \\
43 \\
20\end{array}$ & 34 & & \\
\hline Carangidae & $\begin{array}{l}\text { Seriola grandis } \\
\text { Pseudocaranx dentex } \\
\text { Decapterus koheru } \\
\text { Trachurus spp." }\end{array}$ & $\begin{array}{l}45 \\
23.2 \\
33.7 \\
10.2\end{array}$ & $\begin{array}{r}43.3-47.4 \\
5.5-23.8 \\
27.6-39.7 \\
4-44\end{array}$ & $\begin{array}{r}3 \\
10 \\
150\end{array}$ & 2.4 & $2-8$ & 71 \\
\hline Arripidae & Arripis trutta & 28 & $9-54$ & 134 & & & \\
\hline Emmelichthyidae & Plagiogeneion rubiginosus & 20.3 & $8.5-54$ & 218 & & & \\
\hline Sparidae & Pagrus auratus & 3.3 & & & 3 & $2.9-3.1$ & 6 \\
\hline Mullidae & Upeneichthys lineatus & 21 & $3-38$ & 93 & & & \\
\hline Kyphosidae & $\begin{array}{l}\text { Kyphosus sydneyanus } \\
\text { Girella tricuspidata } \\
\text { Scorpis violaceus }\end{array}$ & $\begin{array}{r}37.4 \\
7.5 \\
25.2\end{array}$ & $\begin{array}{r}15-62.4 \\
5.1-13.4 \\
21.6-32.2\end{array}$ & $\begin{array}{l}10 \\
43 \\
10\end{array}$ & & & \\
\hline Pomacentridae & Chromis dispilus & 4.6 & $4.2-5$ & 2 & 3.8 & $3.3-4.7$ & 5 \\
\hline Mugilidae & Aldrichetta fosteri & 22 & $4-28$ & 340 & 13.5 & $6.2-29$ & 99 \\
\hline Labridae & Pseudolabrus celidotus & 7 & $4.2-10.2$ & 19 & 5.2 & $2.3-9.4$ & 8 \\
\hline Creedidae & Tawera cranwelli & & & & 2.7 & $2.6-3$ & 23 \\
\hline Uranoscopidae & Genyagnus novaezelandiae & & & & 4.2 & $3.5-5$ & 5 \\
\hline Blenniidae & Parablennius laticlavius & 19 & $17.1-21.8$ & 4 & 4.5 & $2.4-11.1$ & 53 \\
\hline Tripterygiidae & $\begin{array}{l}\text { Forsterygion spp." } \\
\text { Notoclinus fenestratus } \\
\text { Gilloblennius spp." }\end{array}$ & $\begin{array}{r}8.2 \\
10.3 \\
8.5\end{array}$ & $\begin{array}{c}2-24.5 \\
6.9-13.5 \\
4-26\end{array}$ & $\begin{array}{r}170 \\
21 \\
409\end{array}$ & $\begin{array}{c}4.3 \\
\mathrm{ND} \\
5.2\end{array}$ & $\begin{array}{l}3-18 \\
3-11\end{array}$ & $\begin{array}{l}150 \\
126\end{array}$ \\
\hline Gobiidae & & & & & 5 & $4.2-6.4$ & 24 \\
\hline Clinidae & Cristiceps auranticus & 16.5 & $14-32$ & 44 & & & \\
\hline Scombridae & Scomber australasicus & 16 & $6.7-63.2$ & 28 & 4.6 & $2.5-6.7$ & 81 \\
\hline Bothidae & Lophonectes gallus & & & & 3.4 & $2.4-5.9$ & 44 \\
\hline Monacanthidae & Parika scaber & 16.2 & $6.7-24$ & 125 & & & \\
\hline $\begin{array}{l}\text { Unknown } \mathrm{A} 6 \\
\text { Unknown } \mathrm{B} 6\end{array}$ & & & & & $\begin{array}{l}4.4 \\
4.5\end{array}$ & $\begin{array}{l}3.3-5.8 \\
4.2-5.2\end{array}$ & $\begin{array}{l}50 \\
27\end{array}$ \\
\hline
\end{tabular}

greatly (Fig. 4). On one occasion (July 1984) high densities of Forsterygion spp. (142 \pm 58 per $100 \mathrm{~g}, \mathrm{n}=$ 3 clumps of algae) were caught around drift algae; however, no comparable estimates were taken in open water. Forsterygion spp. were often the most abundant type of fish in surface waters, between June and December. Although densities were usually higher in open water, largest fish were caught around algae (Table 1). Hence the late developmental forms of Forsterygion spp. may associate with algae. Parablennius laticlavius and Scomber australasicus were mainly caught in open water, but a few large individuals were caught with drift algae (Table 1).

The size-frequency distributions of total fish around drift algae differed from those fish captured in open water samples. Many of the fish captured around drift algae were larger than those caught in open water. For example, in November-December 1982 fish ranged in size from 3 to $103 \mathrm{~mm}$ SL around drift algae (mean $=$ $12 \mathrm{~mm}$ ) and 2 to $13 \mathrm{~mm}$ SL in open water (mean = 
Table 2. Proportional (\%) representation of fish species used to construct the relationships between weight of drift algae clumps and the total numbers of fish in Fig. 3 (Stns C \& D). Underlined percentages mark highest values for that month. D: Decernber; J: January; M: March; A: April; Jn: June; S: September; F: February; O: October; N: November

\begin{tabular}{|c|c|c|c|c|c|c|c|c|c|c|}
\hline \multirow[t]{2}{*}{ Family } & \multirow[t]{2}{*}{ Species } & \multirow{2}{*}{$\begin{array}{l}1981 \\
D-J\end{array}$} & \multicolumn{4}{|c|}{1982} & \multicolumn{3}{|c|}{1983} & \multirow{2}{*}{$\begin{array}{c}1984 \\
\mathrm{D}\end{array}$} \\
\hline & & & $\mathrm{M}-\mathrm{A}$ & $\mathrm{Jn}$ & $\mathrm{S}$ & $D-J$ & $F-M$ & $\mathrm{O}$ & $\mathrm{N}$ & \\
\hline Engraulididae & Engraulis australis & 0.14 & 0 & 0 & 0 & 0.02 & 39 & 0.8 & 0 & 0 \\
\hline Clupeidae & Sardinops neopilchardus & 0 & 0 & 0 & 26 & 0 & 0 & 0 & 0.08 & 0 \\
\hline Galaxiidae & Galaxias maculatus & 0 & 0 & 0 & 0 & 0 & 0 & 1.6 & 0 & 0 \\
\hline Moridae & Pseudophycis spp. & 0 & 0 & 0 & 0 & 0.02 & 0 & 0 & 0 & 0 \\
\hline Hemiramphidae & Hyporhamphus ihi & 0 & 0 & 0 & 0 & 0.02 & 0 & 0 & 0 & 0.07 \\
\hline Syngnathidae & $\begin{array}{l}\text { Lissocampus filum } \\
\text { Stigmatophora longirostris } \\
\text { Hippocampus abdominalis }\end{array}$ & $\begin{array}{l}0.14 \\
0.4 \\
0.8\end{array}$ & $\begin{array}{l}0 \\
1.1 \\
1.1\end{array}$ & $\begin{array}{l}0 \\
7.8 \\
0\end{array}$ & $\begin{array}{l}0 \\
1.4 \\
0.7\end{array}$ & $\begin{array}{l}0 \\
0.2 \\
0.06\end{array}$ & $\begin{array}{l}0 \\
0 \\
1.2\end{array}$ & $\begin{array}{l}0 \\
3.2 \\
1.6\end{array}$ & $\begin{array}{l}0 \\
0 \\
0\end{array}$ & $\begin{array}{l}0 \\
0 \\
0\end{array}$ \\
\hline Carangidae & $\begin{array}{l}\text { Trachurus spp. } \\
\text { Seriola grandis } \\
\text { Caranx georgianus } \\
\text { Decapterus koheru }\end{array}$ & $\begin{array}{l}1.7 \\
0.4 \\
0.14 \\
0\end{array}$ & $\begin{array}{l}\frac{53}{0} \\
0.5 \\
0\end{array}$ & $\begin{array}{l}3.4 \\
0 \\
0 \\
0\end{array}$ & $\begin{array}{l}0 \\
0 \\
0 \\
0\end{array}$ & $\begin{array}{l}0.1 \\
0 \\
0 \\
0\end{array}$ & $\begin{array}{l}3.3 \\
0 \\
0.6 \\
0.6\end{array}$ & $\begin{array}{l}0 \\
0 \\
0 \\
0\end{array}$ & $\begin{array}{l}0 \\
0 \\
0 \\
0\end{array}$ & $\begin{array}{l}0.7 \\
0 \\
0 \\
0\end{array}$ \\
\hline Arripidae & Arripis trutta & 0 & 11.5 & $\underline{52.2}$ & 0 & 0 & 0.3 & 0 & 0 & 0 \\
\hline Emmelichthyidae & Plagiogeneion rubiginosus & 18.8 & 0 & 0 & 0 & 0.02 & $\underline{47}$ & 0 & 0 & 0.7 \\
\hline Mullidae & Upeneichthys lineatus & 0 & 13.1 & 0 & 0 & 0.02 & 0.3 & 0 & 0.08 & 2 \\
\hline Kyphosidae & $\begin{array}{l}\text { Kyphosus sydneyanus } \\
\text { Girella tricuspidata } \\
\text { Scorpis violaceus }\end{array}$ & $\begin{array}{l}0 \\
0 \\
0\end{array}$ & $\begin{array}{l}4.9 \\
0 \\
0\end{array}$ & $\begin{array}{l}0 \\
0 \\
4\end{array}$ & $\begin{array}{l}0 \\
0 \\
1.4\end{array}$ & $\begin{array}{l}0 \\
0.07 \\
0\end{array}$ & $\begin{array}{l}0 \\
0.3 \\
0\end{array}$ & $\begin{array}{l}0 \\
0 \\
0\end{array}$ & $\begin{array}{l}0 \\
0 \\
0\end{array}$ & $\begin{array}{l}0 \\
5.8 \\
0\end{array}$ \\
\hline Pomacentridae & Chromis dispilus & 0.3 & 0 & 0 & 0 & 0 & 0 & 0 & 0 & 0 \\
\hline Mugilidae & Aldrichetta forsteri & 0 & 0 & 0 & 2 & 5.8 & 3.6 & 2.3 & 3 & 2 \\
\hline Labridae & Pseudolabrus celidotus & 0 & 0 & 0 & 3.3 & 0.02 & 0 & 0 & 0.08 & 0 \\
\hline Blenniidae & Parablennius Iaticlavius & 0 & 1.6 & 0 & 0 & 0 & 0 & 0 & 0 & 0 \\
\hline Tripterygiidae & $\begin{array}{l}\text { Gilloblennius spp. } \\
\text { Forsterygion spp. } \\
\text { Notoclinus fenestratus }\end{array}$ & $\begin{array}{l}5.5 \\
0 \\
0\end{array}$ & $\begin{array}{l}0 \\
0 \\
0\end{array}$ & $\begin{array}{r}2.4 \\
12.2 \\
0\end{array}$ & $\begin{array}{l}\frac{32}{3} \cdot 1 \\
0\end{array}$ & $\begin{array}{l}\frac{85.6}{0.5} \\
0.04\end{array}$ & $\begin{array}{l}0 \\
0 \\
0\end{array}$ & $\begin{array}{r}\frac{55.1}{27.5} \\
3.1\end{array}$ & $\begin{array}{l}\frac{81.5}{0.08} \\
0\end{array}$ & $\begin{array}{l}7.8 \\
0 \\
0\end{array}$ \\
\hline Clinidae & Cristiceps auranticus & 2.3 & 1.6 & 4.5 & 0 & 0.2 & 0.6 & 0 & 0 & 5.8 \\
\hline Scombridae & Scomber australasicus & 0 & 8.2 & 0 & 0 & 0.2 & 0 & 0 & 0 & 0 \\
\hline Monacanthidae & Parika scaber & $\underline{69.5}$ & 3.2 & 13.2 & 1.4 & 6.5 & 2.7 & 5.5 & 15.2 & $\underline{74}$ \\
\hline Pleuronectidae & Peltorhamphus latus & 0 & 0 & 0 & 0.7 & 0 & 0 & 0 & 0 & 0 \\
\hline Serranidae type & & 0 & 0 & 0.5 & 1.4 & 0 & 0 & 0 & 0 & 0 \\
\hline $\begin{array}{l}\text { Total no. of fish } \\
\text { Grams of algae }\end{array}$ & & $\begin{array}{r}687 \\
7354\end{array}$ & $\begin{array}{r}185 \\
16535\end{array}$ & $\begin{array}{r}215 \\
34885\end{array}$ & $\begin{array}{r}148 \\
11330\end{array}$ & $\begin{array}{l}4147 \\
2425\end{array}$ & $\begin{array}{r}344 \\
1550\end{array}$ & $\begin{array}{r}129 \\
11640\end{array}$ & $\begin{array}{l}1118 \\
3910\end{array}$ & $\begin{array}{l}1148 \\
1980\end{array}$ \\
\hline
\end{tabular}

$6.5 \mathrm{~mm})$. Most of the larger fish had adult fin-ray counts. Although late developmental forms predominated around drift algae a large number of preflexion larvae were also caught.

\section{Seasonal patterns of drift algae abundance}

Large quantities of drift algae were found at Stns A to $D$ over a period of 30 mo, but abundances of algae found at any one station varied considerably among times (Fig. 5). With the exception of a peak in June 1982, algae were most abundant from November to January at Stn A. Total abundances of algae were high in June after a strong north-easterly storm. There was considerable temporal variability in total abundance of algae at $\operatorname{Stn}$ B (Fig. 5). No obvious seasonal trends could be distinguished. Highest total abundances of algae were found between October and December at Stn C (Fig. 5). From the 16 measurements of total algal abundance made over the study period, there were no clear seasonal peaks at Stn D (Fig. 5).

The fucoid Carpophyllum maschalocarpum was the most abundant species of algae observed at Stn A (Fig. 6a). The seasonal pattern of C. maschalocarpum abundance closely resembled that of total algae. Whenever drift algae were found in large quantities, this species was present. The occurrence of Sargassum sinclairii was strongly seasonal (Fig. 6b). This species was sometimes observed as drift in September and as late as March, but was most abundant between November and January. Carpophyllum plumosum was 
Fig. 3. Relationships between weight of drift algae and number of associated fish at offshore Stns C $(\bullet)$ and D $(\square)$. Correlation coefficients are given where 6 or more algal clumps were sampled. NS $=p>0.05$. The proportional representations of all fish species in each graph are presented in Table 2. (a) December to January 1981 to 82 ; Stn $C, r=0.94$ $\mathrm{n}=16 ;$ Stn $\mathrm{D}, \mathrm{r}=0.99, \mathrm{n}=6$. (b) December to January 1982 to $1983 ; \operatorname{Stn} C, r=0.44, n=23$. (c) February to March 1983; Station $D, r=0.27$ (NS), $\mathrm{n}=7$. (d) December 1984, Stn C, $\mathrm{r}=$ $0.68, \mathrm{n}=10$

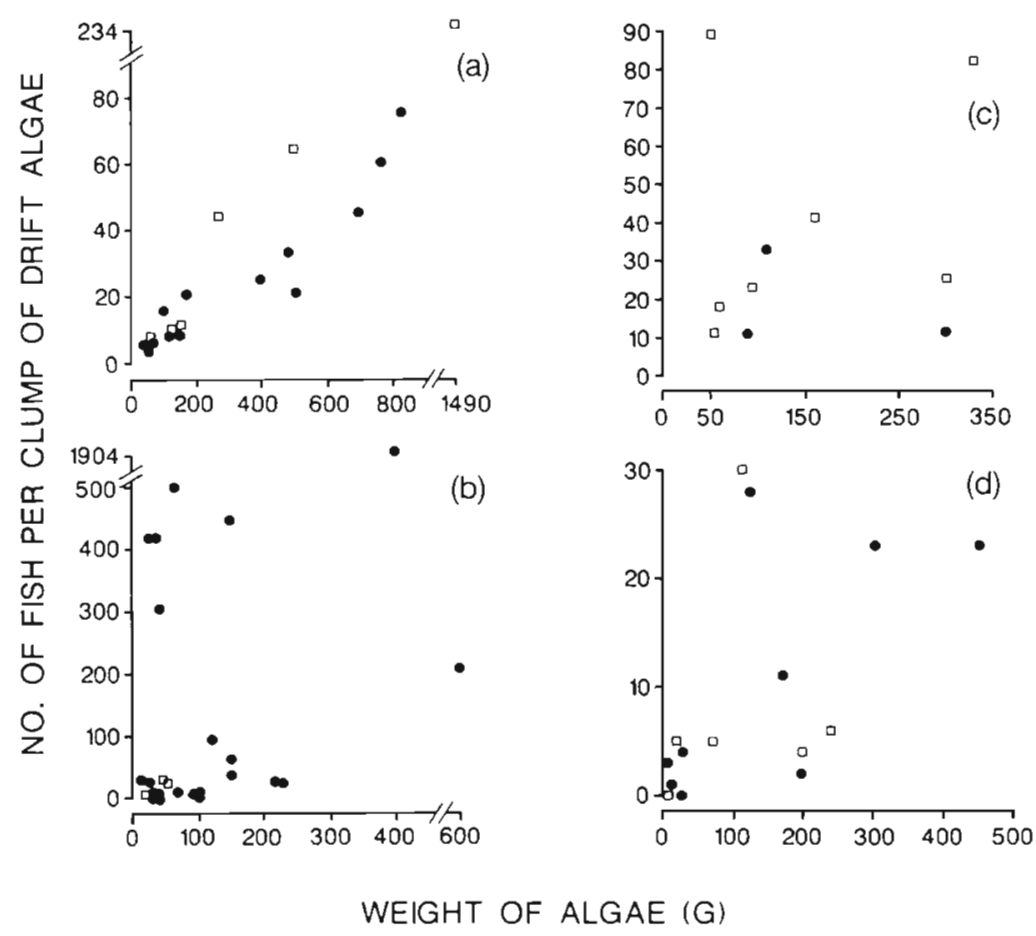

weight. At times, however, a number of large clumps would become intertwined. Bunches estimated to weigh from 5 to $100 \mathrm{~kg}$ were sometimes seen (pers. obs.).

\section{Spatial patterns of drift algae abundance nearshore}

The abundance of drift algae at nearshore sampling Stn A varied among times and localities (Table 3). Although the grand means showed there were differences among localities, no single locality consistently had more drift algae than any other at all of the times examined. Algae were abundant nearshore at some time periods, but almost absent at others. These trends were confirmed by ANOVAs on the data, for the number of clumps and total weight of algae (Table 4). Residual variances in the ANOVAs, and the large standard errors in Table 3 , indicated that algae were patchily distributed within a locality.

\section{Colonisation of experimental algae (Expts 1 and 2)}

Fishes were quickly attracted to soaked algae that were left to drift (Fig. 8). Rapid colonisation rates indicate that small fish found in open water can quickly concentrate around objects introduced to the system. Within 5 to $7 \mathrm{~h}$ many fish had accumulated around previously cleaned algae. The form of the relationship may change between times. In 1981 and 1982 numbers sinclairii and the largest plants were rarely over $3 \mathrm{~kg}$ in at Stns A and B. Most clumps were fragments, not whole plants. In maschalocarpum and C. flexuosum were from a greater 


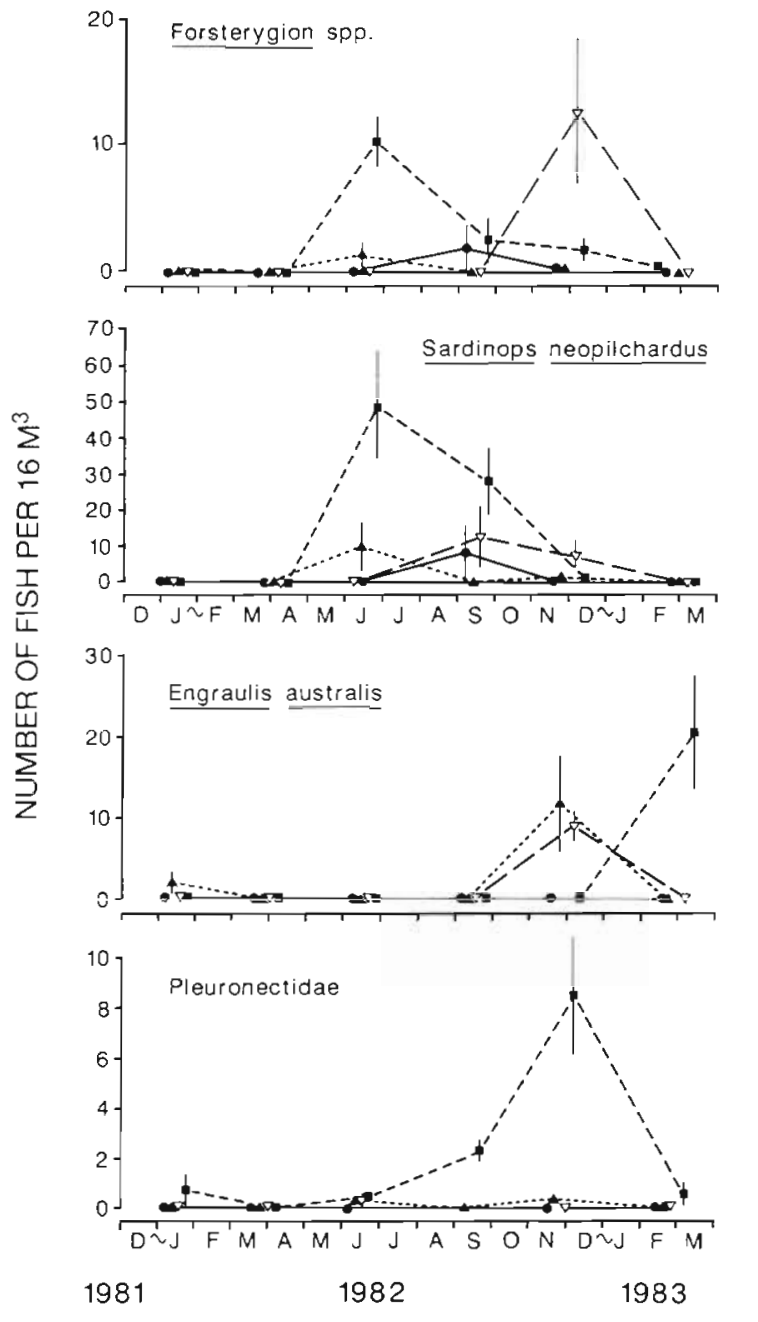

Fig. 4. Numbers of 4 fish taxa associated with drift algae and

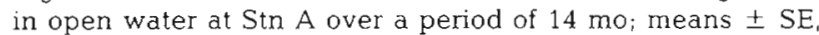
$\mathrm{n}=3$. Symbols as in Fig. 2

of fish increased gradually to ca 20 fish $\mathrm{kg}^{-1}$ algae, but in the following year (1982-83) few fish were found around algae after $4 \mathrm{~h}$ of drift, and after 6 to $7 \mathrm{~h}$ there were 50 fish $\mathrm{kg}^{-1}$ algae. Greater numbers of fish were taken around experimental algae than in control seines of open water (Table 5). With the exception of Girella tricuspidata, maximum numbers of fish captured around experimental algae were 5 to 67 times less than those found around naturally drifting algae.

Parika scaber were quickly attracted to soaked algae (Fig. 8b). The variability in $P$. scaber numbers among replicate clumps of algae was generally small, suggesting that fish approached algae as individuals or in small groups.

In contrast to Parika scaber, when Gilloblennius spp. and Girella tricuspidata were present considerable variability was found among replicate clumps of algae, suggesting they colonise algae in large aggregations

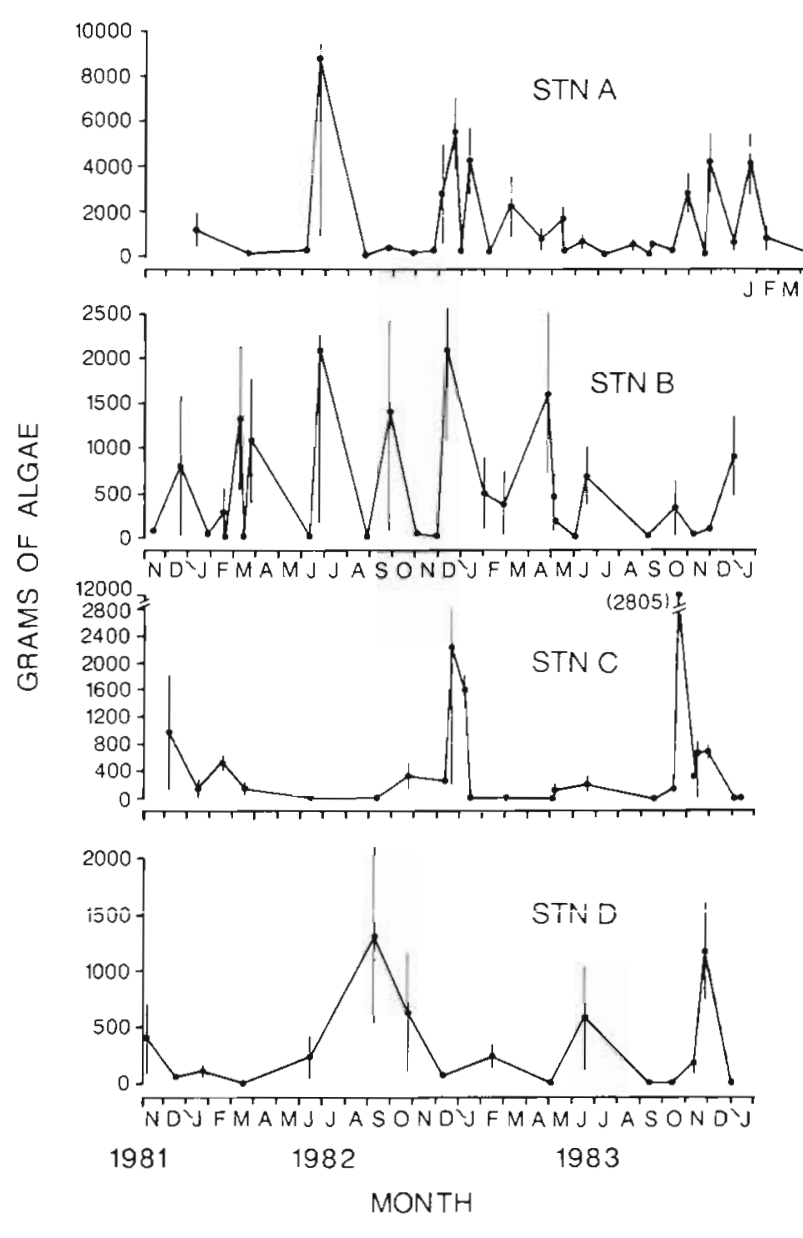

Fig. 5. Seasonal patterns in weight of total drift algae at Stns $A$ to $D$ over a period of $2.5 \mathrm{yr}$ (in grams per 0.8 hectares $(8000$ $\left.\left.\mathrm{m}^{2}\right)\right]$. Means $\pm \mathrm{SE}$; numerals in parentheses $=\mathrm{SE}$

from open water (Fig. 8c, d). A variety of sizes of $P$. scaber, Gilloblennius spp. and Girella tricuspidata colonised soaked algae, and size-frequency relationships closely resembled those of fish around natural drift algae (Fig. 9). Other fish that were found around soaked algae were: Plagiogeneion rubiginosus $(\mathrm{n}=10$, 1981-82), Hyporhamphus ihi ( $\mathrm{n}=1,1981-82)$, Cristiceps auranticus $(\mathrm{n}=1,1981-82)$, Trachurus spp. $(\mathrm{n}=$ $1,1981-82 ; 44,1982-33)$.

Different total densities and species of fish colonised soaked algae at $15 \mathrm{~m}$, when compared to experimental algae in surface waters (Expt 1). A total mean density of $51 \pm 7.1 \mathrm{fish} \mathrm{kg}^{-1}$ algae was found at $15 \mathrm{~m}$, while $16.6 \pm 6.6$ were caught in surface waters after 6.5 to $8 \mathrm{~h}$ of drift (Fig. 8). All of the fish observed at $15 \mathrm{~m}$ were Trachurus spp., while in surface waters ( $\mathrm{n}=50 \mathrm{fish})$, $66 \%$ were Girella tricuspidata, $18 \%$ Parika scaber, $8 \%$ Plagiogeneion rubiginosus, $4 \%$ Gilloblennius spp. and $6 \%$ miscellaneous species. This suggests that small fish 


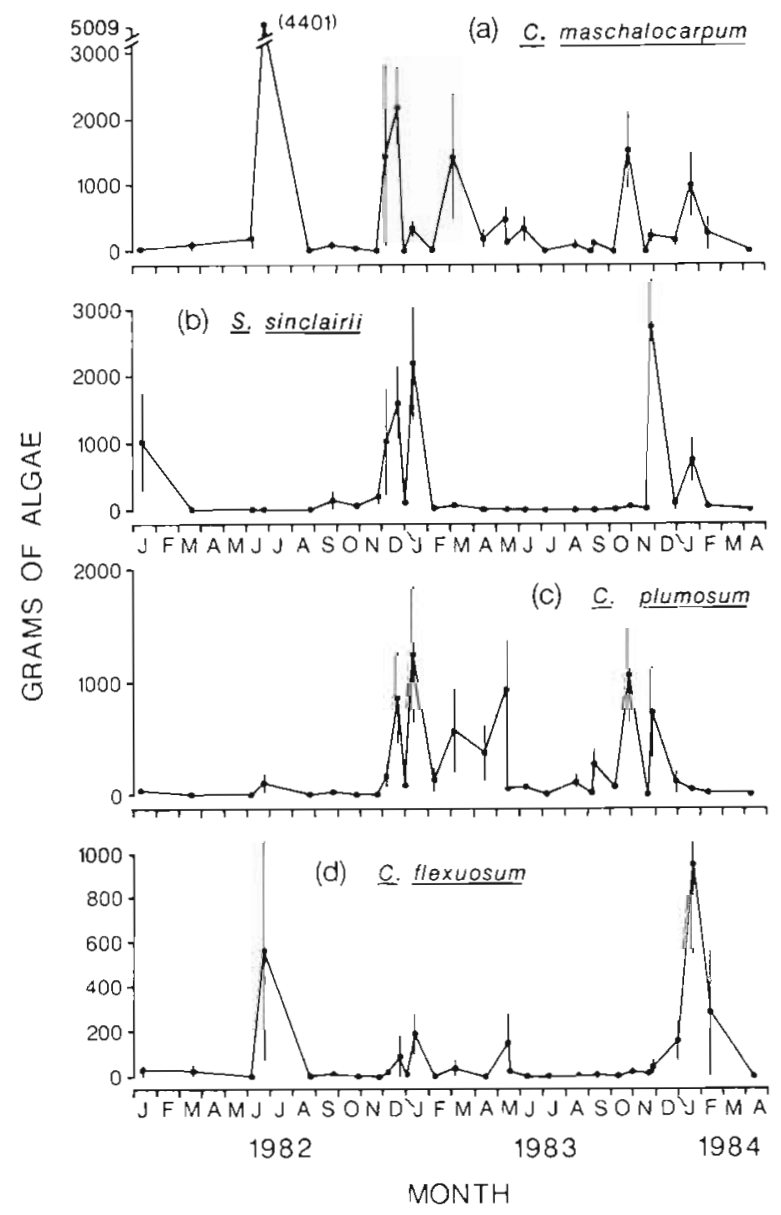

Fig. 6. Carpophyllum spp. and Sargassum sinclairii weight of the 4 most abundant species of drift algae [in grams per 0.8 hectares $\left(8000 \mathrm{~m}^{2}\right)$ l at $\mathrm{Stn}$ A over a period of $2.5 \mathrm{yr}$. Means \pm $\mathrm{SE}_{i}$ numerals in parentheses $=\mathrm{SE}$

of different species occupy different depth strata. Further evidence comes from diver observations (at 10 to $20 \mathrm{~m}$ ) of the fish around jellyfish at Stn A. Fish were counted around scyphomedusae Desmonema chierchianum. A mean of $102 \pm 20$ Trachurus spp. ( $\mathrm{n}=10$ medusae) were observed, and fish that were caught in a diver-controlled plankton net ranged in size from 8 to $23 \mathrm{~mm}$ (mean $=13 \mathrm{~mm}, \mathrm{n}=223$ fish). Small morid cod were also observed with medusae, and on one occasion inside a large salp.

\section{DISCUSSION}

\section{Small fish in surface waters}

High concentrations of small fish were found in association with drift algae and in open water. Some species exhibited a strong affinity for drift algae while others were most abundant in open water and showed no evidence for an association with algae. The families that associated with algae were: monacanthids (Parika scaber), arripids (Arripis trutta), emmelichthyids (Plagiogeneion rubiginosus), carangids (e.g. Trachurus spp.) mugilids (Aldrichetta forsteri), mullids (Upeneichthys lineatus), kyphosids (e.g. Girella tricuspidata), clinids (Cristiceps auranticus), some tripterygiids (Gilloblennius spp.), syngnathids (e.g Stigmatophora longirostris), and some rare groups (Table 1).

With the exception of emmelichthyids, all of the families above have been captured around flotsam and drift algae in other parts of the world (Yabe \& Mori
STATION A
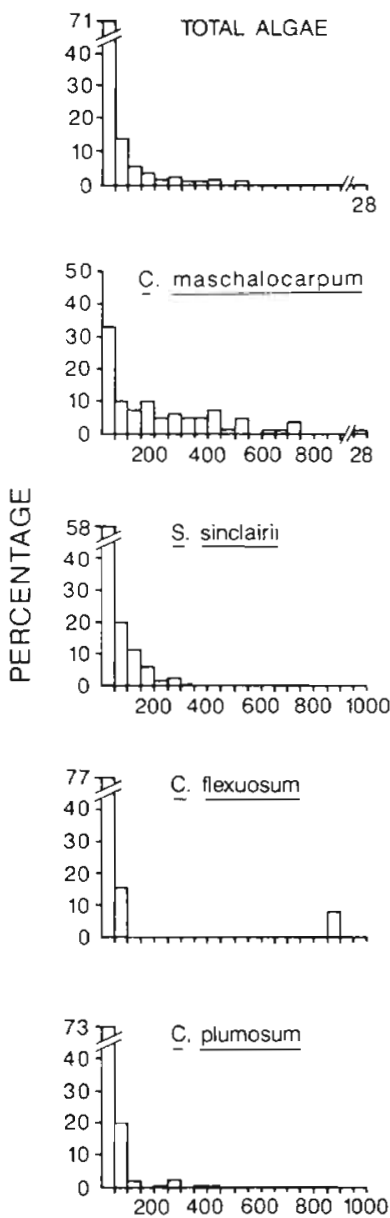

STATION B
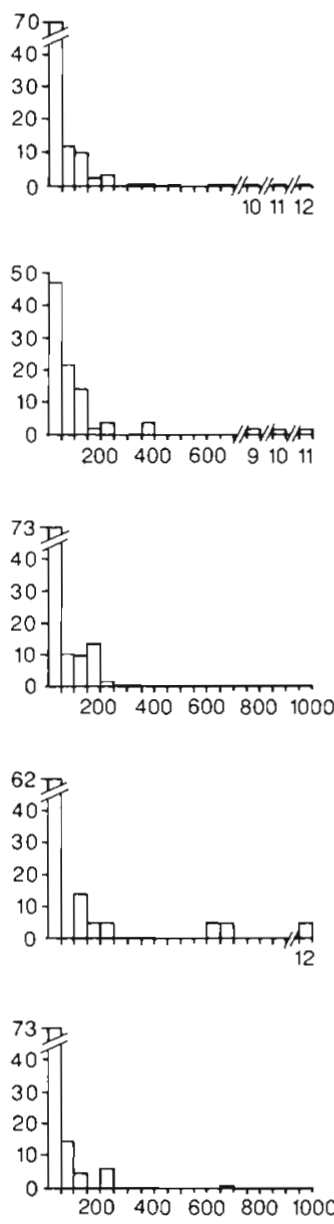

50 G SIZE CLASSES
Fig. 7 Size-frequency distributions of drift algae clumps at Stns A and B. Data are for the total amount of algae measured over spring-summer (1982-83) and the 4 species that ranked first in abundance (Carpophyllum spp. and Sargassum sinclairii). Where the axes are divided, numerals following the normal scale are to be multiplied by $10^{2}$. Number of clumps (Stn A, Stn B): Total algae 994, 350; C. maschalocarpum 83, 49; S. sinclairii 343,212 ; C. flexuosum 13, 21; C. plumosum 271,62 
Table 3. Abundances of algae at 7 localities separated by 400 to $700 \mathrm{~m}$ within Stn A (see Fig. 1). Total weight of algae and number of clumps of algae found at each locality examined at 8 times between 10 October 1983 and 11 April 1984. Localities: (1) Knot Rock, (2) Echinoderm Reef, (3) D Reef, (4) Splendid Reef, (5) Deep Point, (6) Waterfall Reef, (7) Table Top Reef. Densities are expressed as means $\pm S E, n=3$ transects. ANOVAs for these data are given in Table 4

\begin{tabular}{|c|c|c|c|c|c|c|c|c|c|}
\hline Locality & Time: 1 & 2 & 3 & 4 & 5 & 6 & 7 & 8 & Grand mean \\
\hline & \multicolumn{9}{|c|}{ Grams of drift algae per $2000 \mathrm{~m}^{2}$} \\
\hline 1 & 0 & $599 \pm 440$ & $17 \pm 17$ & $312 \pm 172$ & $104 \pm 59$ & $2540 \pm 861$ & 0 & 0 & $444 \pm 306$ \\
\hline 2 & $52 \pm 49$ & $493 \pm 280$ & 0 & $2293 \pm 953$ & $760 \pm 323$ & $1106 \pm 524$ & 0 & 0 & $588 \pm 284$ \\
\hline 3 & $30 \pm 30$ & 0 & $3.3 \pm 3.3$ & $1.7 \pm 1.7$ & 0 & 0 & $1017 \pm 996$ & $5 \pm 5$ & $132 \pm 126$ \\
\hline 4 & $33 \pm 33$ & $2157 \pm 980$ & 0 & $3625 \pm 980$ & 0 & 0 & $157 \pm 73$ & 0 & $747 \pm 488$ \\
\hline 5 & $53 \pm 48$ & $187 \pm 120$ & 0 & $117 \pm 58$ & 0 & $1.7 \pm 1.7$ & 0 & 0 & $44 \pm 25$ \\
\hline 6 & 0 & $170 \pm 170$ & 0 & $13 \pm 13$ & $108 \pm 81$ & $1840 \pm 1835$ & $7 \pm 7$ & 0 & $305 \pm 256$ \\
\hline \multirow[t]{2}{*}{7} & $13 \pm 13$ & $928 \pm 532$ & 0 & $3160 \pm 572$ & $10 \pm 6$ & $1505 \pm 926$ & 0 & $17 \pm 17$ & $704 \pm 404$ \\
\hline & \multicolumn{9}{|c|}{ Number of clumps of algae per $2000 \mathrm{~m}^{2}$} \\
\hline 1 & 0 & $21 \pm 18$ & $0.3 \pm 0.3$ & $9.0 \pm 5.3$ & $3.7 \pm 0.9$ & $18 \pm 3.5$ & 0 & 0 & $6.5 \pm 3.0$ \\
\hline 2 & $1 \pm 0$ & $6.3 \pm 3.8$ & 0 & $14 \pm 5.5$ & $8.3 \pm 2.3$ & $11 \pm 7.2$ & 0 & 0 & $5 \pm 2$ \\
\hline 3 & $0.3 \pm 0.3$ & 0 & $0.3 \pm 0.3$ & $0.3 \pm 0.3$ & 0 & $0.3 \pm 0.3$ & $6.3 \pm 5.4$ & $0.3 \pm 0.3$ & $1.0 \pm 0.8$ \\
\hline 4 & $0.6 \pm 0.3$ & $24 \pm 11$ & 0 & $23 \pm 6.4$ & 0 & 0 & $7 \pm 4$ & 0 & $6.8 \pm 3.7$ \\
\hline 5 & $0.3 \pm 0.3$ & $2 \pm 1$ & 0 & $2.0 \pm 0.6$ & 0 & 0 & 0 & 0 & $0.6 \pm 0.4$ \\
\hline 6 & 0 & $1.7 \pm 1.7$ & 0 & $0.7 \pm 0.7$ & $2.3 \pm 0.7$ & $19 \pm 18$ & $0.3 \pm 0.3$ & 0 & $3.0 \pm 2.3$ \\
\hline 7 & $0.3 \pm 0.3$ & $13 \pm 4.7$ & 0 & $9.3 \pm 1.9$ & $1.0 \pm 0.6$ & $22 \pm 13$ & 0 & $0.6 \pm 0.6$ & $5.8 \pm 2.9$ \\
\hline
\end{tabular}

1950, Gooding \& Magnuson 1967, Hunter \& Mitchell 1967, 1968, Mitchell \& Hunter 1970, Dooley 1972, Eldredge et al. 1978, Lenanton et al. 1982, Robertson \& Lenanton 1984, Safran \& Omori 1990, Kingsford in press). A number of species of fish were abundant in open water that were not found around algae. These included some tripterygiids (Forsterygion spp.), clupeids (Sardinops neopilchardus), engraulids (Engraulis australis), pleuronectids (e.g. Rhombosolea spp.), bothids (Lophonectes gallus) and some other rare groups (Table 1).

Seasonal changes in the abundance of fish around flotsam and drift algae have been found in other investigations (Hunter \& Mitchell 1967, Mitchell \& Hunter 1970, Dooley 1972). In this study large seasonal changes were found in the occurrence and proportional representation of small fish around drift algae. Gilloblennius spp., Parika scaber, and Aldrichetta forsteri were most abundant in spring and summer. In late summer and early autumn Plagiogeneion rubiginosus and Trachurus spp. were found in highest densities, while Arripis trutta were most abundant around algae late in autumn and early in winter.

With the exception of large numbers of preflexion Gilloblennius spp., most of the fish captured with drift algae had adult fin-ray counts. A wide range of sizes was sampled for each species around natural drift. Species captured in the colonisation experiments also exhibited a wide size range. This suggested that fish do not just colonise algae as small unpigmented fish,

Table 4. Results of ANOVA for total weight of algae and number of clumbs found at 7 localities within Stn A. (see Fig. 1). Densities were examined at 8 times. The data for these analyses are in Table 3. Time was treated as a random factor and locality as a fixed factor in both tests. df: degrees of freedom for F-test; C: Cochran's test for homogeneity of the data (56 variances, 2 df) on transformed data; NF: not significant

\begin{tabular}{|c|c|c|c|c|}
\hline Source of variation & MS & $\mathrm{df}$ & $F$ & $\mathrm{p}$ \\
\hline \multicolumn{5}{|c|}{ Total weight of algae, $\log (X+1)$ transiormation, $C=0.1356$, NS } \\
\hline Time & 67.95 & 7,112 & 26.11 & $<0.001$ \\
\hline Locality & 23.5 & 6.42 & 1.69 & NS \\
\hline Time $\times$ Locality & 13.91 & 42,112 & 5.35 & $<0.001$ \\
\hline Residual & 2.60 & 112 & & \\
\hline \multicolumn{5}{|c|}{ Number of algal clumps, $\log (X+1)$ transformation, $C=0.1942$, NS } \\
\hline Time & 64.01 & 7,112 & 21.48 & $<0.001$ \\
\hline Locality & 22.39 & 6,42 & 2.16 & NS \\
\hline Time $\times$ Locality & 72.52 & 42,112 & 4.06 & $<0.001$ \\
\hline Residual & 47.69 & 112 & & \\
\hline
\end{tabular}




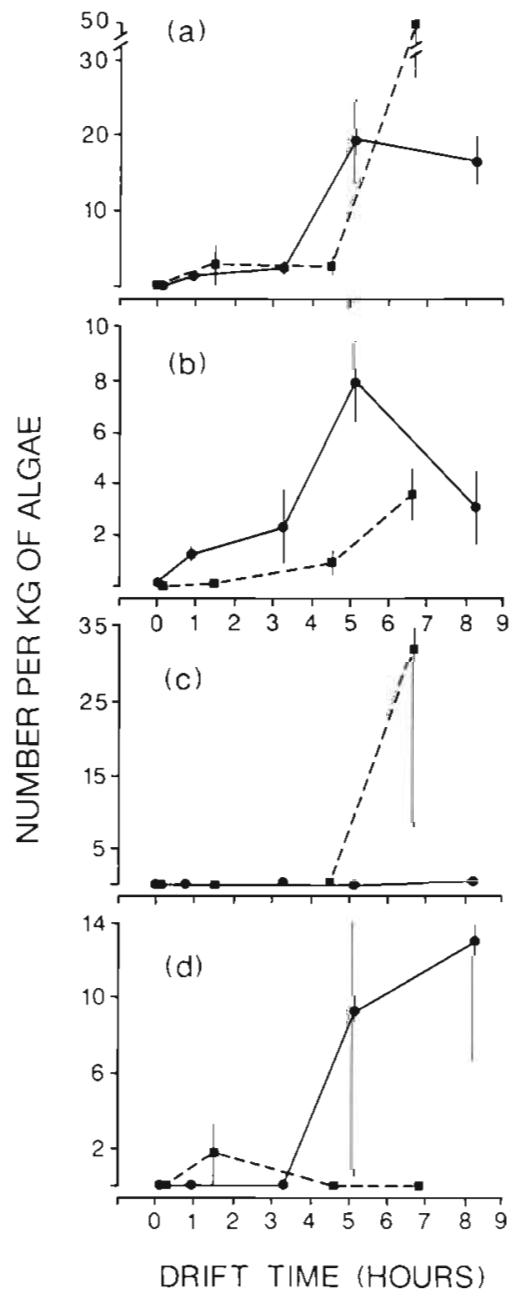

Fig. 8. Carpophyllum maschalocarpum. Colonisation of $1 \mathrm{~kg}$ clumps of experimental algae by fish at Stn C. (•-) 1981-82, $\mathrm{n}=3$ clumps of algae; (- 1982-83, $\mathrm{n}=5$; means \pm SE. (a) Total fish, (b) Parika scaber, (c) Gilloblennius spp., (d) Girella tricuspidata. The number of fish captured in controls from open water are presented in Table 5a

which then remain associated with a single clump of algae after changing into the form of a settled fish. Fish may move around rather than remaining with the first piece of algae they encounter. In addition to small fish in the planktonic phase of their life history, large syngnathids were captured in all seasons. This supports Kingsford \& Choat's (1985) conclusion that drift algae may provide a dispersal mechanism for this secretive group.

The interesting points that emerged from this study of fish around drift algae were: (1) A number of species were seined around algae that were rarely caught in open water with conventional ichthyoplankton nets (e.g. Parika scaber, Plagiogeneion rubiginosus, Cristiceps auranticus). (2) Fish quickly colonised experimental algae that were left to drift. (3) Not all of the fish associated with algae were most abundant in surface

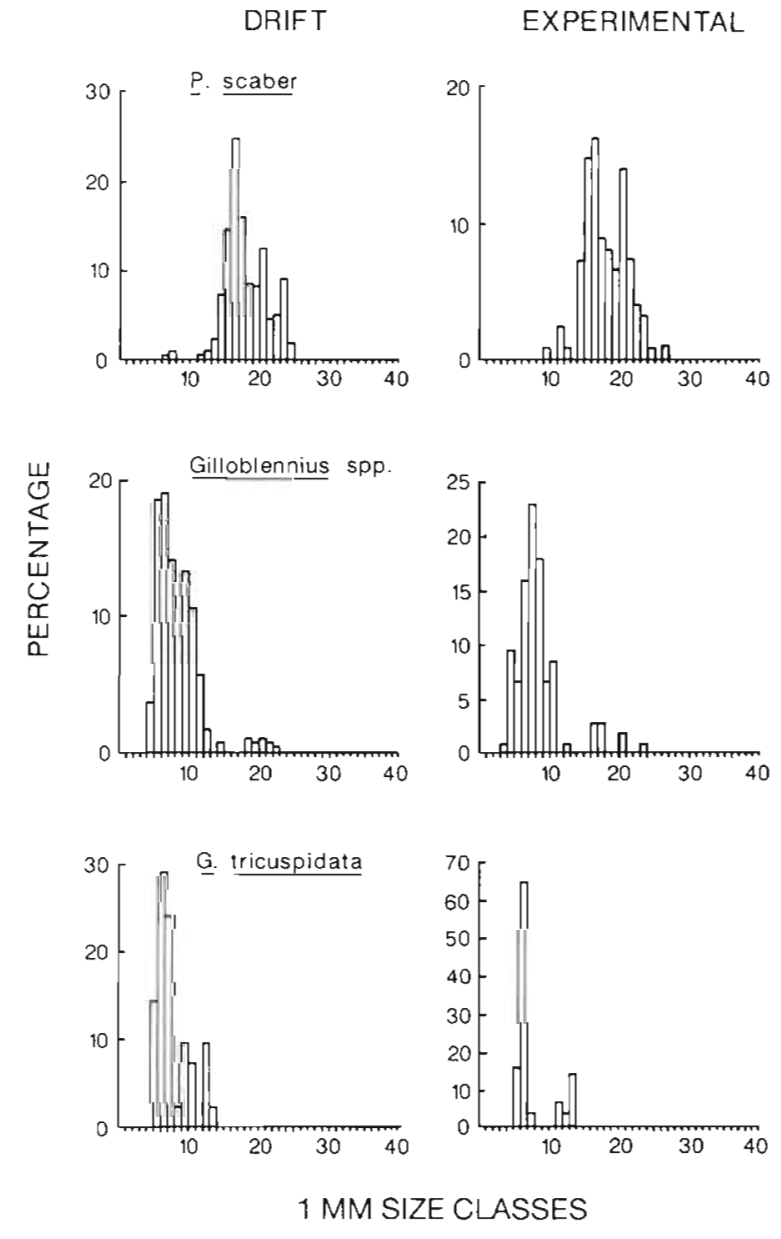

Fig. 9. Parika scaber, Gilloblennius spp. and Girella tricuspidata. Size-frequency of fish around natural drift algae (DRIFT) and soaked algae (EXPERIMENTAL) at Stn C. Data were pooled for Expts 1 and 2 (1981-82 and 1982-83)

waters (e.g. Trachurus spp.). (4) Many of the small fish found in surface waters were juveniles. A number of species were captured in large numbers in my study that have rarely been caught in conventional ichthyoplankton investigations. This suggests one or a combination of the following, given that sampling was carried out during the reproductive period of target species. (1) Inappropriate sampling gear and designs have been used to sample for some species of fishes that live in surface waters. For example, oblique hauls sample neustonic and surface water for a very short time and may undersample the fish in them (Kingsford 1988). For this reason, fish that are relatively common in surface waters (e.g. Aldrichetta forsteri, Parika scaber) are rarely taken in ichthyoplankton surveys which use oblique hauls (see Crossland 1981, 1982). Moreover, few studies have stratified sampling accord- 
Table 5. Colonisation experiment. The results of the 2 control procedures are shown: $\mathrm{S}$, open water control; $\mathrm{S}+\mathrm{N}$, seine plus $1 \mathrm{~kg}$ of natural drift algae. Values represent no. fish per $16 \mathrm{~m}^{3}$ Data on colonisation of algal clumps for the species listed below are presented in Fig. 8

\begin{tabular}{lccc}
\hline Fish & Period & S & $S+N$ \\
\hline (a) Total fish & $1981-1982$ & $0.3 \pm 0.3$ & $100 \pm 19$ \\
(b) Parika scaber & $1982-1983$ & $3.5 \pm 1.5$ & $3120 \pm 227$ \\
& $1981-1982$ & 0 & $77 \pm 20$ \\
(c) Gilloblennius spp. & $1982-1983$ & 0 & $54 \pm 15$ \\
& $1981-1982$ & $0.5 \pm 0.5$ & $0.4 \pm 0.3$ \\
(d) Girella tricuspidata & $1982-1983$ & 0 & $2360 \pm 980$ \\
& $1981-1982$ & 0 & 0 \\
\hline
\end{tabular}

ing to the presence and absence of drift objects. (2) The type of net used to sample surface waters and the speed at which it is towed (Murphy \& Clutter 1972) will determine the size and type of fish caught. (3) Some fish may be found in such low natural densities that estimates of their abundance are not possible with towed nets (see Leis 1981). In this latter case aggregation devices such as natural or artificial drifting objects and light traps (Doherty 1987) may be the only way of revealing the presence of widely dispersed small fish, by concentrating them. It is clear that the methodology used to sample surface waters will have a large influence on resultant patterns. To obtain an overview of the early life history of many fish, a number of methodologies are required.

Some fish are more characteristic of middle or lower depth strata in the water column. For example, Trachurus spp. were found around drift algae, but were more abundant around weighted algae at 10 to $15 \mathrm{~m}$. Trachurus spp. are usually taken in greatest numbers in mid- to lower strata of the water column during the day (Kingsford 1986). Further evidence for this comes from large numbers of this species that were observed around scyphomedusae. The association of Trachurus spp. and cod with jellyfish has been documented in other parts of the world (Dahl 1961, Mansueti 1963, Hay et al. 1990).

Many fish that are found as adults in coastal environments were captured around drift algae and in open water; these included Gilloblennius spp., Forsterygion spp., Parablennius laticlavius, Aldrichetta forsteri, Hyporhamphus ihi, Girella tricuspidata, and Upeneichthys lineatus. Other investigations (Kingsford \& Choat 1986, 1989, Kingsford \& Tricklebank 1991) have found these small fish in surface waters as preflexion larvae and fish with full adult fin-ray counts; this suggests they spend most of their early life history near the surface. Other species (e.g. Parika scaber) were almost always found in surface waters with adult fin-ray counts. Many of the aforementioned fishes were in the form of settled juveniles (but were still presettlement fish), and wide size ranges of each species were captured. This would suggest that many fish spend a considerable amount of time in the pelagic environment in the form of settled juveniles rather than larvae. The distribution patterns of presettlement fish in surface waters, and the chances they have of being transported onshore, will be influenced by their behaviour and the physical processes that affect surface waters (Kingsford 1990).

\section{Factors influencing the association of fish with drift algae}

Fish were quickly attracted to soaked bunches of algae that were left to drift in the colonisation experiments. Since all of the epiphytic invertebrates had been cleared from this algae, the physical structure of algae in the pelagic environment influenced the distribution of fish. The importance of shade attracting fish to floating objects has been thoroughly investigated for freshwater fish (see Helfman 1981). Helfman (1981) suggested that shade is important for increased perception and camouflage from fish, aerial, and terrestrial predators. In marine environments Damant (1921) suggested that fish have a perceptive advantage under floating objects, in that zooplanktonic food is more easily seen from shade than in direct sunlight. Many other workers have suggested that objects enhance conditions for feeding, provide shelter, provide pelagic substratum, and may act as cleaning stations for large fishes (Kojima 1956, Gooding \& Magnuson 1967, Hunter \& Mitchell 1967, 1968, Mitchell \& Hunter 1970, Dooley 1972).

Kingsford \& Milicich (1987) found that small Parika scaber feed on epiphytic invertebrates associated with drift algae (e.g. crab megalopa) as well as zooplankton in surrounding waters. Dooley (1972) and Tully \& O'Ceidigh (1989) found that small fish feed on the 
fauna associated with drift algae, and Yeatman (1962) showed that $25 \mathrm{~mm}$ long flying fish fed on harpacticoid copepods found on drift algae. It is possible, therefore, that some fish are attracted to algae for shelter and the food that is associated with it. This has been suggested for small Cnidoglanis macrocephalus (Plotisidae) associated with detached macrophytes in the surf zone of sandy beaches (Lenanton \& Caputi 1989). A flaw in the colonisation experiments with soaked algae in my study was that colonisation rates may have been higher if epiphytic invertebrates had been present. Fish (e.g. $P$. scaber) may have approached experimental algae, found few megalopa, then moved off to look at other clumps. An appropriate additional treatment would have been to use algae from which crustaceans had not been removed.

The association of fish with drift algae may increase their chances of survival in 2 ways, by concentrating planktonic food that was previously dispersed, and by providing shelter from predators (Kingsford \& Milicich 1987). Predaceous fish were abundant in the study area (e.g. adult Trachurus spp., Sardinops neopilchardus, Engraulis australis, Arripis trutta, Seriola grandis; Clement 1978), and all of these consume planktonic fishes. The gut contents of $24 \mathrm{~A}$. trutta and $4 \mathrm{~S}$. grandis caught on lures during the study contained fish ranging in size from 14 to $200 \mathrm{~mm}$, some of which were small tripterygiids and Aldrichetta forsteri. Thus, small fish may decrease the chance of predation by associating with drift algae when it is encountered.

\section{Distribution of drift algae}

Although drift algae were found at all times of the year, especially after storms, there was considerable variation in the abundances at different times of the year. Some species of algae, however, were extremely predictable in their seasonal occurrence. Regardless of the station sampled, Sargassum sinclairii were only found during the spring-summer period, with peak abundances from November to January (see Kingsford in press). This seasonality conforms well with Schiel's (1985) data on attached $S$. sinclairii near Goat Island. S. sinclairii shed most of the thallus during the later stages of reproduction, over spring. Furthermore, the survivorship of attached algae drops over this period. The abundances of other drift algal species either strongly resembled the pattern for total drift algae (e.g. Carpophyllum maschalocarpum) or showed no strong seasonal patterns (e.g. C. flexuosum). Gilloblennius spp. and Parika scaber were the most abundant fish associated with drift algae when total abundances and $S$. sinclairi abundances peaked. It is probable, therefore, that drift algae are likely to influence the distribution and survivorship of these fish species more than any others.

The dispersal of drifting algae is interesting in terms of the population dynamics of the algae and the dispersal of organisms other than fish. Dispersal of spores from attached adult plants within an area of reef is often restricted to a few metres, except during storms (Reed et al. 1988). Drift algae may disperse spores over much greater spatial scales, among reefs. Although most invertebrates quickly vacate plants when they are experimentally detached from reefs (Kingsford \& Choat 1985), casual observations show that large isopods and amphipods are occasionally found on drift algae. Some invertebrates may disperse over long distances with drift, as suggested by Highsmith (1985) and Locke \& Corey (1989).

Even when there were seasonal peaks in the abundance of drift algae, there were rapid changes within any given period. This was true at both nearshore and offshore stations. It was clear that algae were moving into and out of areas between sampling dates. This was also apparent in the distribution patterns of drift algae with distance from shore (Kingsford \& Choat 1986). At times algae were most abundant offshore, whereas at other times algae were found at all stations, or mainly nearshore. This suggested 3 main points: (1) By moving into an area drift algae may quickly change the distributions of some fish types, especially those that are well dispersed in open water. (2) If fish stay with drift algae for some time, the movements of the algae will determine those of the fish. (3) Where algae often drift toward shore, this may result in increased recruitment rates of fish found nearshore as adults.

The investigation of algal abundances at nearshore localities indicated that density of drift algae varies temporally. When storm events had not recently detached algae from rocky reefs, an accumulation of algae nearshore suggested it was the result of onshore transport. The physical mechanisms that may cause aggregation and movements of drift algae include wind and internal waves (Shanks 1983, Kingsford \& Choat 1986, Kingsford 1990). When algae are transported onshore, the recruitment of fish to nearshore localities may vary depending on where algae first reach shore. Average quantities of drift algae found over the spring-summer period varied among localities nearshore. The results indicated, however, that the accumulation of algae was not predictable at any one locality. Thus, the ranking of localities varied considerably over short time periods. This suggested that patchiness in the pelagic environment (i.e. fish around algae) may cause small-scale variability in temporal patterns of recruitment among localities during conditions of onshore transport. Throughout a recruitment period, however, some localities may receive more fish from 
drift algae than others, and this may generate localscale variation in recruitment patterns (e.g. Jones 1984).

This study has shown that fish associate with drift algae at all times of the year. Furthermore, fish quickly colonise algae introduced to the pelagic environment. Since drift algae were predictably abundant over spring and summer, these are the times that algae may have its greatest influence on the distribution of fish. Sampling drift objects can provide a source of small fish, in good condition, that are difficult to obtain using conventional towed nets in open water. The physical conditions that move algae around in surface waters may provide some insight into factors influencing the recruitment of fish that live as adults nearshore. Finally, to obtain an overview of the early life history of fish a number of methodologies are required.

Acknowiedgements. This research was supported by a New Zealand Fisheries Research Division Scholarship to M. J. Kingsford. Additional financial support was provided by the Leigh Marine Laboratory. A project of this nature demands considerable assistance in boats; I especially thank M. Atkinson, M. Meekan, M. Uffindell, P. Leake, D. Allen and N. Keenlyside. Thanks to J. H. Choat for his enthusiastic interest in the study and ecological advice. Helpful comments and criticisms of the study were provided by J. Leis, J. H. Choat and 3 anonymous referees.

\section{LITERATURE CITED}

Benz, C. M., Eiseman, N. J., Gallaher, E. E. (1979). Seasonal occurrence and variation in standing crop of a drift algal community in the Indian River, Florida. Botanica mar. 22: $413-420$

Clement, I. I (1978). School fish sightings around New Zealand, 1976-1977. Occas. Publ, N.Z. Fish. Res. Div, 15: $35-42$

Crossland, J. (1981). Fish eggs and larvae of the Hauraki Gulf, New Zealand. Fish. Res. Bull. N.Z. Minist. Agric. Fish. 23: $1-61$

Crossland, J. (1982). Distribution and abundance of fish eggs and larvae from the spring-summer plankton of northeast New Zealand, 1976-78. Fish. Res. Bull. N.Z. Minist. Agric. Fish. 24: 1-59

Dahl, E. (1961). The association between young whiting, Gadus merlangus, and the jelly-fish Cyanea capillata. Sarsia 3: 47-55

Damant, G. C. C. (1921). Illumination of plankton. Nature, Lond. 108: 42-43

Doherty, P. J. (1987). Light-traps: selective but useful devices for quantifying the distributions and abundances of larval fishes. Bull. mar. Sci. 41. 423-431

Dooley, J. K. (1972). Fishes associated with the pelagic Sargassum complex, with a discussion of the Sargassum community. Contr. mar. Sci. 16: 1-32

Eldredge, P. J., Berry, F. G., Miller, M. C. (1978). Diurnal variations in catches of selected species of ichthyoneuston by the neuston net off Charlston, Southern Carolina. Fish. Bull. U.S. 76: 295-297

Gooding, R. M., Magnuson, J. J. (1967). Ecological signifi- cance of a drifting object to pelagic fishes. Pacif. Sci. 21 486-497

Hay, S. J., Hispol, J. R. G., Shanks, A. M. (1990). North Sea Scyphomedusae-summer distribution, estimated biomass and significance particularly for 0-group gadoid fish. Neth. J. Sea Res. 25: 113-130

Helfman, G. S. (1981). The advantage to fishes of hovering in shade. Copeia 2: 392-400

Highsmith, R. C. (1985). Floating and algal rafting as potential dispersal mechanisms in brooding invertebrates. Mar. Ecol. Prog. Ser. 25: 169-179

Hunter, J. R., Mitchell, C. T. (1967). Association of fishes with flotsam in the offshore waters of Central America. Fish. Bull. U.S. 66: 13-29

Hunter, J. R., Mitchell, C. T. (1968). Field experiments on the attraction of pelagic fish to floating objects. J. Cons. perm. int. Explor. Mer. 31: 427-434

Janssen, J., Harbison, G. R. (1981). Fish in salps: the association of squaretails (Tetragonurus spp.) with pelagic tunicates. J. mar, biol. Ass. U.K. 61: 917-927

Jones, G. P. (1984). Population ecology of a temperate reef fish Pseudolabrus celidotus Bloch \& Schneider (Pisces: Labridae). II. Factors influencing recruitment. J. exp. mar. Biol. Ecol. 75: 257-276

Kingsford, M. J. (1986). The distribution patterns of fish during the planktonic period of their life history. Ph.D. thesis, University of Auckland

Kingsford, M. J. (1988). The early life history of fish in coastal waters of northern New Zealand: a review. N. Z. Jl mar. Freshwat. Res. 22: 463-479

Kingsford, M. J. (1990). Linear oceanographic features: a focus for research on recruitment processes. Aust. J. Ecol. 15: $27-37$

Kingsford, M. J. (in press). Biotic and abiotic structure in the pelagic environment: importance to small fish. Contri. Sci.

Kingsford, M. J., Choat, J. H. (1985). The fauna associated with drift algae captured with a plankton-mesh purse seine net. Limnol. Oceanogr. 30: 618-630

Kingsford, M. J., Choat, J. H. (1986). Influence of surface slicks on the distribution and onshore movements of small fish. Mar. Biol. 91: 161-171

Kingsford, M. J., Choat, J. H. (1989). Horizontal distribution patterns of presettlement fish: are they influenced by the proximity of reefs? Mar. Biol. 100: 285-297

Kingsford, M. J., Milicich, M. J. (1987). Presettlement phase of Parika scaber (Pisces: Monacanthidae): a temperate reef fish. Mar. Ecol. Prog. Ser 36: 65-79

Kingsford, M. J., Tricklebank, K. (1991). Ontogeny and Behaviour of Aldrichetta forsteri. Copeia 1. 9-16

Kojima, S. (1956). Fishing for dolphins in the western part of the Japan Sea-II. Why do the fish take shelter under floating materials? Bull. Jap. Soc. scient. Fish. 21. 1049-1051

Legendre, L., Demers, S. (1984). Towards dynamic biological oceanography and limnology. Can. J. Fish. Aquat. Sci. 41: 2-19

Leis, J. M. (1981). Distribution of fish larvae around Lizard Island, Great Barrier Reef: coral reef Iagoon refuge? In: Gomez, G. D. et al. (eds.) Proc 4 th int. Symp. Coral Reefs 2: 472-477. Marine Sciences Center, University of the Philippines, Quezon City

Leis, J. M., Rennis, D. S. (1983). The larvae of Indo-Pacific coral reef fishes. New South Wales University Press, Sydney

Lenanton, R. C. J., Caputi, N. (1989). The roles of food supply and shelter in the relationship between fishes, in particular Cnidoglanis macrocephalus (Valenciennes), and detached 
macrophytes in the surf zone of sandy beaches. J. exp. mar. Biol. Ecol. 128: 165-176

Lenanton, R. C. J., Robertson, A. I., Hansen, J. A. (1982). Nearshore accumulations of detached macrophytes as nursery areas for fish. Mar. Ecol. Prog. Ser. 9: 51-57

Locke, A., Corey, S. (1989). Amphipods, isopods and surface currents: a case for passive dispersal in the Bay of Fundy, Canada. J. Plankton Res. 11: 419-430

Mansueti, R. (1963). Symbiotic behaviour between small fishes and jellyfishes, with new data on that between the stromateid, Peprilus alepidotus, and the Scyphomedusa, Chrysaora quinquecirrha. Copiea 1: 40-80

Mitchell, C. T., Hunter, J. R. (1970). Fishes associated with drifting kelp, Macrocystis pyrifera, off the coast of southern California and northern Baja California. Calif. Dep. Fish Game Fish Bull. 56: 288-297

Murphy, G. I., Clutter, R. I. (1972). Sampling anchovy larvae with a. plankton-mesh purse seine. Fish. Bull. U.S. 70: 789-798

Prince, J. S., O'Neal, S. W. (1979). The ecology of Sargassum pteropleuron Grunow (Phaeophyceae, Fucales) in the waters off South Florida. I. Growth, reproduction and population structure. Phycologia 18: 109-114

Reed, D. C., Laur, D. R. Ebeling, A. W. (1988). Variation in algal dispersal and recruitment: the importance of episodic events. Ecol. Monogr. 58: 937-948

This article was submitted to the editor
Robertson, A. I., Lenanton, R. C. J. (1984). Fish community structure and food chain dynamics in the surf-zone of sandy beaches: the role of detached macrophyte detritus. J. exp. mar. Biol. Ecol. 84: 265-283

Safran, P., Omori, M. (1990). Some ecological observations on fishes associated with drifting seaweed off Tohoku coast, Japan. Mar. Biol. 105: 395-402

Schiel, D. R. (1985). Growth, survival and reproduction of two species of marine algae at different densities in natural stands. J. Ecol. 75: 199-217

Shanks, A. L. (1983). Surface slicks associated with tidally forced internal waves may transport pelagic larvae of benthic invertebrates and fishes shoreward. Mar. Ecol. Prog. Ser. 13: 311-315

Tully, O., O'Ceidigh, P. (1989). The ichthyoneuston of Galway Bay (west of Ireland). II. Food of post-larval and juvenile neustonic and pseudoneustonic fish. Mar. Ecol. Prog. Ser. 51: $301-310$

Yabe, H., Mori, $T$ (1950). An observation on the habit of bonito, Katsuwonus vagans, and yellow fin, Neothunnus macropterus, school under the drifting timber on the surface of ocean. Bull. Jap. Soc. scient. Fish. 16: 35-39

Yeatman, H. C. (1962). The problem of dispersal of marine littoral copepods in the Atlantic Ocean, including some redescriptions of species. Crustaceana $4: 253-272$

Manuscript first received: February 26, 1991

Revised version accepted: December 19, 1991 